\title{
TESTS ON THE MECHANICAL PROPERTIES OF POLYMERS IN THE ASPECT OF AN ATTEMPT TO DETERMINE THE PARAMETERS OF THE MOONEY- RIVLIN HYPERELASTIC MODEL
}

\author{
Klaudia ŚLIWA-WIECZOREK ${ }^{1}$, Bogusław ZAJĄC ${ }^{2}$, Tomasz KOZIK ${ }^{3}$ \\ ${ }^{1}$ Chair of Bridge, Metal and Timber Structures,Faculty of Civil Engineering, Cracow \\ University of Technology, Poland \\ ${ }^{2}$ Chair of Structural Mechanics and Material Mechanics, Faculty of Civil Engineering, \\ Cracow University of Technology, Poland \\ ${ }^{3}$ PalettenWerk Kozik Spółka Jawna, Cracow, Poland
}

\begin{abstract}
The article presents testing of the mechanical properties of SIKA ${ }^{\circledR}$ polymer adhesives of the type PBM, PMM, PM, and PSM in the aspect of an attempt to determine the parameters of the Mooney-Rivlin hyperelastic model. The article contains a literature review on developed models for hyperelastic materials as well as a description of the author's own results obtained in monaxial tensile and monaxial compression tests conducted on oars and cylindrical samples, respectively. Furthermore, the results of modeling of Mooney-Rivlin hyperelastic model parameters are shown in relation to the value of average parameters for polymers after both a week and a month-and-a-half of ripening.
\end{abstract}

Keywords: hyperelastic model, hyperelasticity, polymers, adhesive joint, deformation, stresses

\footnotetext{
${ }^{1}$ Corresponding author: Chair of Bridge, Metal and Timber Structures, Faculty of Civil Engineering, Cracow University of Technology, Warszawska Street 24, 31-155 Cracow, klaudia.sliwa-wieczorek@pk.edu.pl
} 


\section{INTRODUCTION}

Polymers are classified to those chemical substances that are of particular interest in the world of science and industry because of the dynamic nature of technical progress in the area of plastics development (including synthetic polymers) as well as the shaping of flexible joints based on adhesives (including polyurethane and polymer adhesives) $[16,17]$.

Flexible adhesives based on polyurethane are the materials used for the tests described in this article. These adhesives are primarily used for reinforcements and repairs to masonry and concrete structures. Their main feature is the ability to transfer significant deformations, which is important in the event of an influence on the structure, e.g. strong winds, earthquakes or large temperature gradients [8]. In addition, polyurethane adhesives are characterized by a very low glass-transition temperature owing to the fact that, in a polymer, there is a change of its elastic-brittle or elastic mechanical state with forced elasticity into a highly elastic state [20]. This characteristic indicates that there are very stable mechanical parameters under normal atmospheric conditions, in contrast to, e.g. epoxy resins, which are characterized by a significant reduction in stiffness and strength at temperatures above $+40{ }^{\circ} \mathrm{C}[6]$.

The objective of the article is an attempt to determine the value of the MooneyRivlin hyperelastic model parameters for the tested materials based on the results obtained in monaxial tensile and monaxial compression tests, conducted on polymers in oars and cylindrical samples, respectively, after both a week and a month-and-a-half of ripening.

\section{OVERVIEW OF HYPERELASTIC MATERIAL MODELS}

Polymer materials may be described using a model of hyperelastic material [7]. The material is referred to as a hyperelastic type for which there exists such a function - W (called elastic potential), which has scalar values and whose argument is a measure of material deformation such that the constitutive compound can be written as the following equation [18]:

$$
T=\frac{\partial W}{\partial E} \Leftrightarrow S_{i j}=\frac{\partial W}{\partial E_{i j}} i, j=1,2,3
$$

In the case of isotropic materials, the deformation energy functions depend on the so-called invariants of deformation [11].

A detailed review of the models has been described in both foreign $[1,4,11,13]$ and national literature $[5,6,8,9,12]$. Jemioło describes in detail the simplest models of isotropic hyperelasticity with division into non-compressible, low 
compressible, and compressible materials, widely implemented in the FEM finite element method.

There are several models of hyperelastic materials, one of the main (first) examples being the Mooney-Rivlin model, most frequently used in practical calculations. It predicts the behavior of isotropic materials similar to rubber material with high accuracy. Other models are, for instance, the Ogden model, the Blatz-Ko model, or the neo-Hookean model, this being Rivlin's previous proposal. For this model, we can distinguish the elastic potential for compressible and non-compressible material. The generalization of the noncompressible neo-Hookean model is the Gent material model, discussed, e.g. in the work [18]. Another model used mainly for rubber-derived non-compressible materials is the Yeoh material model.

In addition, attention should be paid to the dynamic development of numerical methods, which allows describing more and more precisely materials used not only in construction but also in interdisciplinary fields of science such as biomedicine, where a key role is played by the possibility of simulating the behavior of materials under the influence of load, causing significant deformations. Exemplary questions of the hyperelastic models' application in biomechanics, used to describe the material intended for orthopedic liners, can be found in the study [10].

\section{MECHANICAL PROPERTIES OF POLYMERS TESTS AND AN ATTEMPT TO DETERMINE THE PARAMETERS OF THE MOONEY-RIVLIN HYPERELASTIC MODEL}

\subsection{Tested materials}

The tests were conducted on samples made of four types of two-component polyurethane adhesives manufactured by Sika ${ }^{\circledR}$ : PBM, PMM, PM, and PSM. The adhesives used in the tests (polyurethane-based) are dedicated to adhesive joints in the scope of making flexible joints, and particularly in damaged masonry and concrete structures.

The authors notice that the mechanical properties of polymeric adhesives are closely related to the temperature and speed of deformation of the material over time. Structural changes that occur under the influence of the load affect the mechanical parameters, and this ought to be taken into consideration in the design process of flexible joints. Therefore, in the case of the tests, three deformation speeds at ambient temperature were taken into account.

Tests were also carried out in the aspect of the possibility of using polymeric adhesives for flexible joints in timber structures. For this purpose, the criterion determining a minimum polymer tensile strength not less than $0.5 \mathrm{MPa}$ as well 
as the limit of deformability at a level not less than 5\% was assumed. This should ensure the strength of the timber-polymer connection at a level not less than 0.5 MPa. The results of these studies are described in the authors' publication [19].

\subsection{Description of mechanical properties tests - monaxial testing of unlimited stretching and compression}

The first kind of research conducted was a monaxial, unlimited tensile test, which was carried out on oar-shaped fittings in accordance with ASTM standards ASTMD-638-03:2004 Standard test method for tensile properties of plastics [2], PN-EN ISO 527-1:2012 Plastics - Determination of mechanical properties with static stretching - Part 1: General principles [14]. The total length of the sample was increased to $200 \mathrm{~mm}$ in accordance with Fig. 1 (presented below) in order to protect the fitting against breaking or sliding in the grips of the testing machine. The sample thickness was $4 \mathrm{~mm}$, while the measuring section length was $50 \mathrm{~mm}$. All samples were checked before testing for squareness, flatness, and edge straightness.

The samples were seasoned in a place with stable humidity of $20 \%$. The test was conducted for two polymer ripening periods, i.e. after 7 days and after 1.5 months from the time of performance.

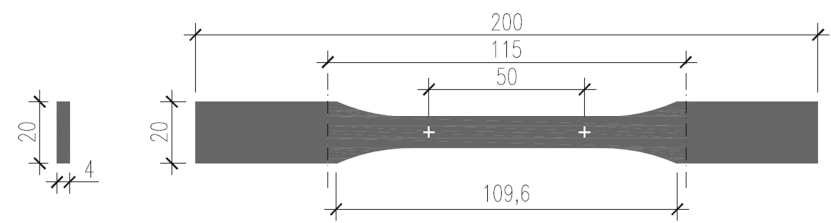

Fig. 1. The sample shape subjected to monaxial unlimited stretching

The test was carried out at ambient humidity and temperature using the following deformation rates:

- $10^{-1} \cdot 1 / \mathrm{min}$ for 6 elements for each of the polymers tested (PBM, PMM, PM, and PSM),

- $10^{0} \cdot 1 / \mathrm{min}$ for 6 elements for each of the polymers tested,

- $10^{1} \cdot 1 / \mathrm{min}$ for 6 elements for each of the polymers tested.

During the test, the force $\mathrm{F}$ and the corresponding increase in the length of the measuring section, and the distance between the grips of the testing machine were recorded. Tensile stress values were calculated on the basis of the formula [15]:

$$
\sigma=\frac{F}{A}
$$


where: $\sigma$ - nominal value of stress in $\mathrm{MPa}, \mathrm{F}-$ registered force value in $\mathrm{N}, \mathrm{A}-$ initial section area in $\mathrm{mm}^{2}$.

Deformation values in stretching were calculated on the basis of the formula [15]:

$$
\varepsilon=\frac{\Delta L_{0}}{L_{0}}
$$

where: $\varepsilon$ - deformation, expressed in dimensionless-ness or as a percentage, $\Delta \mathrm{L}_{0}$ - increase in the length of the fitting between measuring marks in $\mathrm{mm}, \mathrm{L}_{0}-$ measuring section length of the fitting for the tests in $\mathrm{mm}$.

Another type of research conducted was the monaxial unlimited compression test, which was performed on cylindrical samples with a diameter of $28 \mathrm{~mm}$ and a height of $28 \mathrm{~mm}$, as presented in Fig. 2a. The samples were loaded with a quasi-static load in accordance with ASTM standards D 695-02a: 2002 Standard test method for compressive properties of rigid plastics [3]. The samples were seasoned in a place with stable humidity of $20 \%$. The test was conducted for two polymer ripening periods, i.e. after 7 days and after 1.5 months from the time of performance.

a)

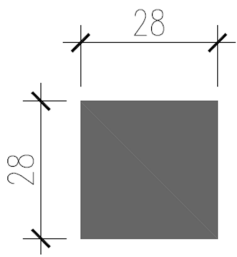

Fig. 2. Sample subjected to monaxial unlimited compression: a) sample shape;

b) view of the sample in the machine

The materials were tested in a testing machine at the following deformation speeds:

- $10 \% \mathrm{~L}_{0} \cdot 1 / \mathrm{min}=10^{-1} \cdot 1 / \mathrm{min}$ for 6 elements for each of the polymers tested (PBM, PMM, PM, and PSM),

- $100 \% \mathrm{~L}_{0} \cdot 1 / \mathrm{min}=10^{0} \cdot 1 / \mathrm{min}$ for 6 elements for each of the polymers tested,

- $1000 \% \mathrm{~L}_{0} \cdot 1 / \mathrm{min}=10^{1} \cdot 1 / \mathrm{min}$ for 6 elements for each of the polymers tested.

The values of $\sigma_{\mathrm{M}}$ stresses and deformations $\varepsilon_{\mathrm{M}}$ under compression were calculated using formulas (3.1) and (3.2) respectively, while the deformations in the case of the compression test have the character of relative shortening. 


\subsection{Mechanical properties tests results - monaxial tests of unlimited stretching and compression}

The test results for monaxial unlimited stretching of polymers are depicted in Table 1, in which there are the maximum stress values and maximum deformation values in statistical terms for each of the three test speeds $\left(10^{-1}\right.$, $10^{0}$, and $\left.10^{1} \cdot 1 / \mathrm{min}\right)$. For each type of Sika ${ }^{\circledR}$ adhesive tested, the average value of tensile stress $(\mathrm{m})$, standard deviation (s) and coefficient of variation (V) were calculated

Table 1. The results for monaxial tensile testing

\begin{tabular}{|c|c|c|c|c|c|c|c|}
\hline $\begin{array}{c}\text { Type of } \\
\text { polymer }\end{array}$ & \multicolumn{3}{c|}{ Stresses $\sigma_{\mathrm{M}}$ in MPa } & \multicolumn{3}{c|}{ Deformation $\varepsilon_{\mathrm{M}}$ in $\%$} \\
\hline \multicolumn{2}{|c|}{ Test speed } & $10^{-1} \cdot 1 / \mathrm{min}$ & $10^{0} \cdot 1 / \mathrm{min}$ & $10^{1} \cdot 1 / \mathrm{min}$ & $10^{-1} \cdot 1 / \mathrm{min}$ & $10^{0} \cdot 1 / \mathrm{min}$ & $10^{1} \cdot 1 / \mathrm{min}$ \\
\hline \multirow{3}{*}{ PBM } & $\mathrm{m}$ & 0.3710 & 0.5040 & 0.6990 & 566.30 & 602.00 & 586.90 \\
\cline { 2 - 9 } & $\mathrm{s}$ & 0.0786 & 0.0947 & 0.1300 & 82.20 & 28.60 & 5.30 \\
\cline { 2 - 8 } & $\mathrm{V}$ in $\%$ & 21.18 & 18.78 & 18.59 & 14.52 & 4.75 & 0.91 \\
\hline \multirow{4}{*}{ PMM } & $\mathrm{m}$ & 0.9980 & 1.1700 & 1.5500 & 196.10 & 222.30 & 281.30 \\
\cline { 2 - 8 } & $\mathrm{s}$ & 0.0818 & 0.0908 & 0.0848 & 26.30 & 16.50 & 26.30 \\
\cline { 2 - 8 } & $\mathrm{V}$ in $\%$ & 8.19 & 7.73 & 5.46 & 13.44 & 7.41 & 9.34 \\
\hline \multirow{4}{*}{ PM } & $\mathrm{m}$ & 1.2200 & 1.4400 & 1.7100 & 90.90 & 105.00 & 145.50 \\
\cline { 2 - 8 } & $\mathrm{s}$ & 0.1510 & 0.0787 & 0.1920 & 21.90 & 4.30 & 22.10 \\
\cline { 2 - 8 } & $\mathrm{V}$ in $\%$ & 12.38 & 5.47 & 11.23 & 24.11 & 4.10 & 15.19 \\
\hline \multirow{3}{*}{ PSM } & $\mathrm{m}$ & 2.2000 & 2.5000 & 3.0500 & 155.70 & 174.30 & 205.60 \\
\cline { 2 - 8 } & $\mathrm{s}$ & 0.1260 & 0.1790 & 0.1590 & 5.90 & 7.30 & 22.30 \\
\cline { 2 - 8 } & $\mathrm{V}$ in $\%$ & 5.73 & 7.14 & 5.22 & 3.77 & 4.17 & 10.85 \\
\hline
\end{tabular}

As presented in Table 1:

- for PSM polymer, the highest stresses were registered $\sigma_{\mathrm{M}} \mathrm{W}$ in case of each value test speed $\left(2.2000,2.5000\right.$, and $3.0500 \mathrm{MPa}$ for test speed $10^{-1}, 10^{0}$, and $10^{1} \cdot 1 / \mathrm{min}$, respectively)

- the smallest variability in nominal stresses appeared to be PSM polymers for test speed $10^{-1}$ and $10^{1} \cdot 1 / \mathrm{min}(\mathrm{V}=5.73$ and $5,22 \%$, respectively) and PM for test speed $10^{0} \cdot 1 / \mathrm{min}(\mathrm{V}=5.47 \%)$,

- the largest variation in nominal stresses results was observed for the PBM polymer regardless of the speed test ( $\mathrm{V}$ size 21.18, 18.78, and $18.59 \%$, respectively, for test speed $10^{-1}, 10^{0}$, and $10^{1} \cdot 1 / \mathrm{min}$ ),

- for the PBM polymer, the largest deformation values $\varepsilon_{\mathrm{M}}$ were recorded for each test speed value $(566.30,602.00$, and $586.90 \%$, respectively, for test speed $10^{-1}, 10^{0}$ and $\left.10^{1} \cdot 1 / \mathrm{min}\right)$, 
TESTS ON THE MECHANICAL PROPERTIES OF POLYMERS IN THE ASPECT OF AN 7 ATTEMPT TO DETERMINE THE PARAMETERS OF THE MOONEY-RIVLIN

HYPERELASTIC MODEL

- the smallest variation in the size of deformations appeared to be PSM polymers for the test speed $10^{-1}$ and $10^{0} \cdot 1 / \mathrm{min}(\mathrm{V}=3.77$ and $4.17 \%$, respectively) and PBM for test speed $10^{1} \cdot 1 / \mathrm{min}(\mathrm{V}=0.91 \%)$,

- the largest variation in deformation results was observed for PM polymers for test speed $10^{-1}$ and $10^{1} \cdot 1 / \mathrm{min}(\mathrm{V}=24.11$ and $15.19 \%$, respectively) and PMM for test speed $10^{\circ} \cdot 1 / \mathrm{min}(\mathrm{V}=7.41 \%)$.
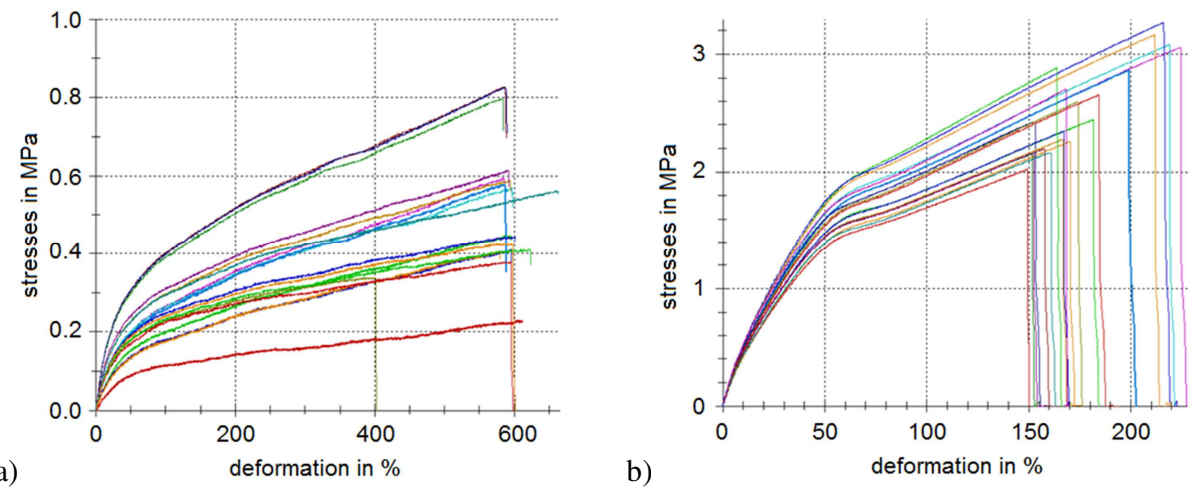

Fig. 3. Charts of stresses dependence on polymers deformation: a) PBM, b) PSM

Fig. 3 shows the resulting curves for unlimited tensile tests for selected PBM and PSM polymers. The charts illustrate the dependencies of stresses $\sigma_{M}$ on deformation $\varepsilon_{\mathrm{M}}$.

Table 2. Results for the monaxial compression test

\begin{tabular}{|c|c|c|c|c|c|c|c|}
\hline $\begin{array}{c}\text { Type of } \\
\text { polymer }\end{array}$ & \multicolumn{3}{c|}{ Stresses $\sigma_{\mathrm{M}}$ in MPa } & \multicolumn{3}{c|}{ Relative shortening $\varepsilon_{\mathrm{M}}$ in \% } \\
\hline \multicolumn{2}{|c|}{ Test speed } & $10^{-1} \cdot 1 / \mathrm{min}$ & $10^{0} \cdot 1 / \mathrm{min}$ & $10^{1} \cdot 1 / \mathrm{min}$ & $10^{-1} \cdot 1 / \mathrm{min}$ & $10^{0} \cdot 1 / \mathrm{min}$ & $10^{1} \cdot 1 / \mathrm{min}$ \\
\hline \multirow{3}{*}{ PBM } & $\mathrm{m}$ & 32.50 & 32.50 & 36.80 & 93.70 & 93.30 & 94.00 \\
\cline { 2 - 9 } & $\mathrm{s}$ & 0.00879 & 0.04540 & 0.66600 & 0.50 & 0.40 & 0.40 \\
\cline { 2 - 8 } & $\mathrm{V}$ in \% & 0.03 & 0.14 & 1.81 & 0.48 & 0.39 & 0.39 \\
\hline \multirow{4}{*}{ PMM } & $\mathrm{m}$ & 32.50 & 32.50 & 35.40 & 88.70 & 88.30 & 88.60 \\
\cline { 2 - 8 } & $\mathrm{s}$ & 0.00391 & 0.05010 & 0.26400 & 0.20 & 0.20 & 0.10 \\
\cline { 2 - 8 } & $\mathrm{V}$ in $\%$ & 0.01 & 0.15 & 0.75 & 0.20 & 0.25 & 0.07 \\
\hline \multirow{3}{*}{ PM } & $\mathrm{m}$ & 32.50 & 32.50 & 35.10 & 88.40 & 87.70 & 87.60 \\
\cline { 2 - 8 } & $\mathrm{s}$ & 0.00840 & 0.01980 & 0.13800 & 0.20 & 0.30 & 0.10 \\
\cline { 2 - 8 } & $\mathrm{V}$ in $\%$ & 0.03 & 0.06 & 0.39 & 0.26 & 0.37 & 0.08 \\
\hline \multirow{3}{*}{ PSM } & $\mathrm{m}$ & 32.50 & 32.50 & 34.40 & 82.50 & 81.50 & 81.50 \\
\cline { 2 - 8 } & $\mathrm{s}$ & 0.00656 & 0.04090 & 0.08100 & 0.10 & 0.10 & 0.40 \\
\cline { 2 - 8 } & V in $\%$ & 0.02 & 0.13 & 0.24 & 0.10 & 0.13 & 0.44 \\
\hline
\end{tabular}


The test results for monaxial unlimited compression of polymers are shown in Table 2, in which there are the maximum stress values and maximum deformation values in statistical terms (similar to the unlimited tensile test) for each of three test speeds $\left(10^{-1}, 10^{0}\right.$, and $\left.10^{1} \cdot 1 / \mathrm{min}\right)$. For each type of $\mathrm{Sika}^{\circledR}$ adhesive tested, the average value of compressive stress (m), standard deviation $(\mathrm{s})$, and coefficient of variation $(\mathrm{V})$ were calculated.

As presented in Table 2:

- for all polymers tested (PBM, PMM, PM, and PSM), the same average value of compressive stress $\sigma_{\mathrm{M}}=32.50 \mathrm{MPa}$ for test speed $10^{-1}$ and $10^{0} \cdot 1 / \mathrm{min}$ was observed,

- for the PBM polymer, the largest average stress rate was recorded in the case of the test speed $10^{1} \cdot 1 / \mathrm{min}\left(\sigma_{\mathrm{M}}=36.80 \mathrm{MPa}\right)$,

- PMM polymers showed the smallest variation in the size of nominal stresses for test speed $10^{-1} \cdot 1 / \mathrm{min}(\mathrm{V}=0.01 \%), \mathrm{PM}$ for test speed $10^{0} \cdot 1 / \mathrm{min}(\mathrm{V}=$ $0.06 \%)$, and PSM for test speed $10^{1} \cdot 1 / \mathrm{min}(\mathrm{V}=0.24 \%)$,

- the largest variety in nominal stresses results was observed for PBM and PM polymers for test speed $10^{-1} \cdot 1 / \mathrm{min}(\mathrm{V}=0.03 \%)$, PMM for test speed $10^{0} \cdot 1 / \mathrm{min}(\mathrm{V}=0.15 \%)$, and $\mathrm{PBM}$ for test speed $10^{1} \cdot 1 / \mathrm{min}(\mathrm{V}=1.81 \%)$,

- the maximum variety of nominal stress results was only $1.81 \%$, which indicates a very high consistency of the results recorded during the tests of nominal stresses, with monaxial unlimited compression,

- the largest relative shortening $\varepsilon_{\mathrm{M}}$ values were recorded for each test speed value $\left(93.70,93.30\right.$, and $94.00 \%$, respectively, at test $10^{-1}, 10^{0}$, and $10^{1} \cdot 1 / \mathrm{min}$ ) for the PBM polymer,

- the smallest variability of relative shortening size were PSM polymers for test speed $10^{-1}$ and $10^{\circ} \cdot 1 / \mathrm{min}(\mathrm{V}=0.10$ and $0.13 \%$, respectively) and PMM for test speed $10^{1} \cdot 1 / \min (\mathrm{V}=0.07 \%)$,

- the greatest variety of relative shortening results was observed for PBM polymers for test speed $10^{-1}$ and $10^{\circ} \cdot 1 / \mathrm{min}(\mathrm{V}=0.48$ and $0.39 \%$, respectively) as well as PSM for test speed $10^{1} \cdot 1 / \mathrm{min}(\mathrm{V}=0.44 \%)$,

- the maximum variety of relative shortening was only $0.48 \%$, which indicates a very high consistency of the results recorded during relative shortening tests with monaxial unlimited compression. 
Fig. 4 presents the result curves for unlimited compression tests for selected PBM and PSM polymers. The charts illustrate the dependencies of stresses $\sigma_{M}$ on relative shortening $\varepsilon_{\mathrm{M}}$.
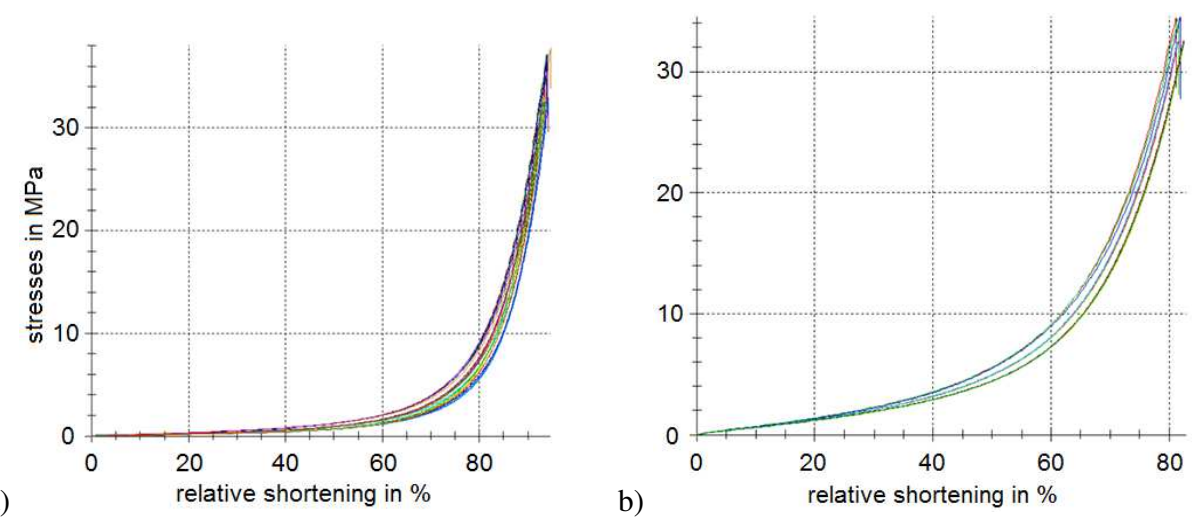

Fig. 4. Charts of stresses dependence on polymers relative shortening: a) PBM, b) PSM

\subsection{Mooney-Rivlin hyperelastic model parameterization}

The multinominal form of constitutive equations takes the following form:

$$
W=\sum_{i+j=1}^{N} C_{i j}\left(\bar{I}_{1}-3\right)^{i}\left(\bar{I}_{2}-3\right)^{j}+\sum_{i=1}^{N} \frac{1}{D_{i}}\left(J_{e l}-1\right)^{2 i}
$$

For the parameter $\mathrm{N}=1$, the equation takes the form of the deformation potential energy of the Mooney-Rivlin form (M-R) with the following value:

$$
W^{M-R}=C_{10}\left(\bar{I}_{1}-3\right)+C_{01}\left(\bar{I}_{2}-3\right)+\frac{1}{D_{1}}\left(J_{e l}-1\right)^{2}
$$

where: $\mathrm{C}_{10}, \mathrm{C}_{01}$, and $\mathrm{D}_{1}$ are constant materials which are dependent on temperature, $I_{1}$ and $I_{2}$ are the first and second invariants of the deformation matrix deviator, respectively, and $\mathrm{J}_{\mathrm{el}}$ is the elastic increase in volume as a result of thermal expansion.

Assuming a constant material temperature, the elastic energy potential of the Mooney-Rivlin model is described by the equation:

$$
W^{M-R}=C_{10}\left(\bar{I}_{1}-3\right)+C_{01}\left(\bar{I}_{2}-3\right)
$$

Based on the work [9] for the model of hyperelastic material (3.3), a simplified formula of the equation (3.6) can be determined which shows the relationship 
between the nominal stress and the multinomial model $\mathrm{N}=1$ (Mooney-Rivlin equation) for incompressible material.

The procedure for determining the Mooney-Rivlin model constants is based on the algorithm for minimizing the mean square error for equation (3.7), transformed from equation (3.6) as follows [20]:

$$
\begin{gathered}
\frac{P}{A_{0}}=2 \cdot\left(1-\frac{1}{\lambda^{3}}\right) \cdot\left(\lambda \cdot C_{10}+C_{01}\right) \\
\sigma(\lambda)=\frac{P}{A_{0}}=C_{10} \cdot\left(2 \lambda-\frac{2}{\lambda^{2}}\right)+C_{01} \cdot\left(2-\frac{2}{\lambda^{3}}\right)
\end{gathered}
$$

where: $\mathrm{P}$ is the value of the compressive force, $\mathrm{A}_{0}$ is the cross-sectional area of the sample, and $\lambda$ is the stretching. $C_{10}$ and $C_{01}$ material constants are the parameters determined from monaxial tension or compression tests. After transformations, we obtain a straight line equation, explained in detail in the study [20].

Based on the results of our research conducted and described in chapter 3.3, the parameters of the Mooney-Rivlin hyperelastic model were determined for each of the polymers (PBM, PMM, PM, and PSM). The results are presented in graphic form, separately for two polymer ripening periods, i.e. 7 days and 1.5 months after the samples were made, taking into consideration three different deformation rates.

Fig. 5 illustrates the sizes of parameters obtained from experimental results in the monaxial tensile test as well as the average parameters for the Mooney line for an exemplary deformation speed which is $10^{-1} \cdot 1 / \mathrm{min}$ for the 7 -day period of polymer ripening.
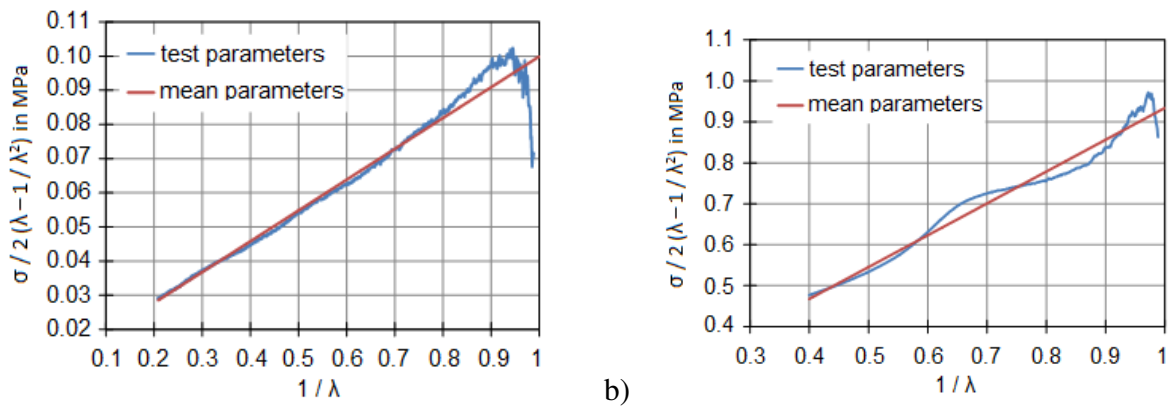

Fig. 5. Mooney graph for the polymer after 7 days of ripening: a) PBM, b) PSM 
Fig.6 illustrates the values of parameters obtained from experimental results in the monaxial compression test as well as the average parameters for the Mooney line for an exemplary deformation speed of $10^{-1} \cdot 1 / \mathrm{min}$ for a 7 -day period of polymer ripening.
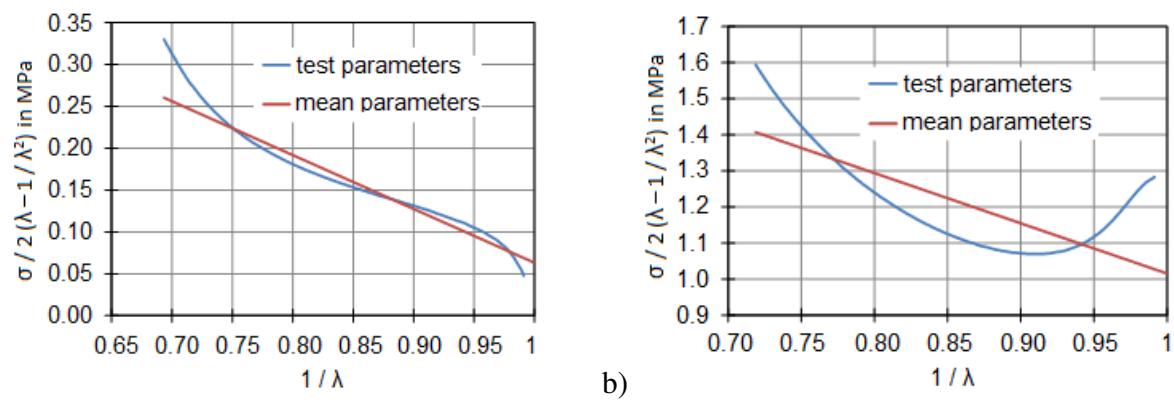

Fig. 6. Mooney graph for the polymer after 7 days of ripening: a) PBM, b)PSM

Corresponding sets of Mooney charts were obtained for the polymers tested in the 1.5-month period of polymer ripening with both monaxial tension and monaxial compression.

The parameters of the Mooney-Rivlin model for all tested polymers and the full scope of deformation for all three deformation growth rates $\left(10^{-1}, 10^{0}\right.$, and $10^{1} \cdot 1 / \mathrm{min}$ ) are presented in tabular form. Based on the $\mathrm{C}_{01}$ and $\mathrm{C}_{10}$ material constants constituting the parameters of the linear function, the initial shear modulus $\mathrm{G}_{0}$ and the initial modulus of longitudinal elasticity $\mathrm{E}_{0}$ were estimated using the following dependencies:

$$
\begin{gathered}
G_{0}=2\left(C_{10}+C_{01}\right) \\
E_{0}=3 G=6\left(C_{10}+C_{01}\right)
\end{gathered}
$$

Obtained values of the Mooney-Rivlin model parameters for the 7-day polymer ripening period are presented in Table 3. 
Table 3.Parameter values for the Mooney-Rivlin model (7-day polymer ripening period)

\begin{tabular}{|c|c|c|c|c|c|c|c|c|c|}
\hline \multirow{2}{*}{\multicolumn{2}{|c|}{$\begin{array}{c}\text { Type of } \\
\text { polymer and } \\
\text { test speed }\end{array}$}} & \multicolumn{4}{|c|}{ Tensile test } & \multicolumn{4}{|c|}{ Compression test } \\
\hline & & $\mathrm{C}_{01}$ & $\mathrm{C}_{10}$ & $\mathrm{E}_{0}$ & $\mathrm{G}_{0}$ & $\mathrm{C}_{01}$ & $\mathrm{C}_{10}$ & $\mathrm{E}_{0}$ & $\mathrm{G}_{0}$ \\
\hline \multirow{3}{*}{ 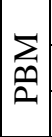 } & $10^{-1} \cdot 1 / \min$ & 0.090 & 0.010 & 0.600 & 0.200 & -0.563 & 0.619 & 0.334 & 0.111 \\
\hline & $10^{0} \cdot 1 / \mathrm{min}$ & 0.069 & 0.020 & 0.536 & 0.179 & -0.541 & 0.693 & 0.910 & 0.303 \\
\hline & $10^{1} \cdot 1 / \mathrm{min}$ & 0.105 & 0.026 & 0.781 & 0.260 & -0.670 & 0.881 & 1.266 & 0.422 \\
\hline \multirow{3}{*}{$\sum_{\Sigma}$} & $10^{-1} \cdot 1 / \mathrm{min}$ & 0.384 & 0.042 & 2.559 & 0.853 & -0.290 & 0.857 & 3.401 & 1.134 \\
\hline & $10^{0} \cdot 1 / \mathrm{min}$ & 0.376 & 0.057 & 2.597 & 0.866 & -0.452 & 1.022 & 3.419 & 1.140 \\
\hline & $10^{1} \cdot 1 / \mathrm{min}$ & 0.405 & 0.082 & 2.920 & 0.973 & -0.543 & 1.139 & 3.579 & 1.193 \\
\hline \multirow{3}{*}{$\sum_{1}$} & $10^{-1} \cdot 1 / \min$ & 8.172 & -4.661 & 21.065 & 7.022 & 0.560 & 0.380 & 5.640 & 1.880 \\
\hline & $10^{0} \cdot 1 / \mathrm{min}$ & 7.854 & -4.128 & 22.355 & 7.452 & 0.020 & 0.930 & 5.660 & 1.890 \\
\hline & $10^{1} \cdot 1 / \min$ & 7.888 & -3.931 & 23.741 & 7.914 & -0.150 & 1.150 & 6.050 & 2.020 \\
\hline \multirow{3}{*}{$\sum_{\infty}$} & $10^{-1} \cdot 1 / \mathrm{min}$ & 0.777 & 0.157 & 5.604 & 1.868 & -0.290 & 0.857 & 3.401 & 1.134 \\
\hline & $10^{0} \cdot 1 / \mathrm{min}$ & 0.697 & 0.185 & 5.293 & 1.764 & -1.456 & 2.547 & 6.550 & 2.183 \\
\hline & $10^{1} \cdot 1 / \mathrm{min}$ & 0.726 & 0.242 & 5.803 & 1.934 & -1.653 & 2.832 & 7.072 & 2.357 \\
\hline
\end{tabular}

\section{CONCLUSIONS}

Based on the results obtained from the monaxial tensile test (Table 3), it can be concluded that the PBM, PMM, PM, and PSM polymers are characterized by parameters characteristic for hyperelastic materials as the experimental curves have been satisfactorily adjusted to Mooney's straight line.

On the basis of the result values for nominal stresses $\sigma_{M}$ and deformations $\varepsilon_{M}$ in the monaxial tensile test (Table 1), the following relationship was observed between the maximum values of strain during stretching as well as deformation on the speed of deformation. With the increase of deformation speed, the value of maximum strain and deformation increased during the test. A deviation from this rule was observed only for deformation of the PBM polymer, the value of which was the highest at a speed of $10^{\circ} \cdot 1 / \mathrm{min}$.

In terms of the possibility to apply polymers in susceptible timber-polymer joints, it has been observed in accordance with the assumed criteria that all polymers except PBM meet the adopted criterion concerning a minimum tensile strength of $0.5 \mathrm{MPa}$.

What is more, it was observed that the obtained average tensile strength values exceeded the minimum value of $0.5 \mathrm{MPa}$ and the limit deformability above $5 \%$, with the exception of the PBM polymer, which did not reach the required level for the test speed of $10^{-1} \cdot 1 / \mathrm{min}$, and for the speed $10^{0} \cdot 1 / \mathrm{min}$, the result was just on the minimum limit.

However, the axial compression test did not confirm the positive results of the monaxial tensile tests. Based on the results obtained, it is very difficult to 
classify polymers to a group of hyperelastic materials. A satisfactory result of adjusting the experimental curve from the tests to Mooney's straight line in the full scope of deformation was achieved only for the PBM polymer. Thus, it may be concluded that the tested materials should be better described by the Hooke linear-elastic model under compression.

\section{ACKNOWLEDGMENTS}

The tests were conducted as a part of the project entitled "Development of an innovative modular construction technology, based on prefabricated timber." by Palettenwerk Kozik Registered Partnership within the Intelligent Development Operational Program for 2014-2020 (Priority axis I. Support for conducting R \& D works by enterprises, operation $1.1 \mathrm{R} \& \mathrm{D}$ projects for enterprises, Suboperation 1.1.1. Industrial study as well as development works performed by enterprises).

\section{REFERENCES}

1. Aidy, A, Hosseini, M and Sahari, B 2010. A review of constitutive models for rubber-like materials. American Journal of Engineering and Applied Sciences, 3, 1, 232-239.

2. ASTM D-638-03:2004. Standard Test Method for Tensile Properties of Plastics, ASTM.

3. ASTM D 695-02a:2002. Standard Test Method for Compressive Properties of Rigid Plastics, ASTM.

4. Darijani, H, Naghdabadi, R and Kargarnovin, MH 2010. Constitutive modeling of rubberlike materials based on consistent strain energy density functions. Polymer Engineering and Science, 50, 1058-1066.

5. Jemioło, S 2016. Elasticity and hyperelasticity: modeling and applications. (Sprężystość i hipersprężystość: modelowanie i zastosowania), Warszawa: Oficyna Wydawnicza Politechniki Warszawskiej.

6. Klamer, EL, Hordijk, DA and Hermes, MC 2008. The influence of temperature on $\mathrm{RC}$ beams strengthened with externally bonded CFRP reinforcement, Heron, 53, 3, 157-185.

7. Kwiecień, A, Latus, P and Zając, B 2011. Attempt to build a rheological model of the PM polymer and analysis of its accuracy based on experimental studies " (Próba budowy modelu reologicznego dla polimeru pm i analiza dokładności tego modelu na podstawie badań doświadczalnych). Czasopismo Techniczne. Środowisko, 108, 3-Ś, 93-110.

8. Kwiecień, A 2012. Polymer flexible joints in masonry and concrete structures. (Polimerowe złącza podatne w konstrukcjach murowych i betonowych), Kraków: Wydawnictwo Politechniki Krakowskiej. 
9. Kwiecień, A 2015. Modeling of constitutive equations of hyperelastic polymers in susceptible joints. (Modelowanie równań konstytutywnych polimerów hipersprężystych w złączach podatnych), In: Garstecki, A., Gilewski, W. and Pozorski, Z. (ed) (Wspótczesna mechanika konstrukcji w projektowaniu inżynierskim), Polska Akademia Nauk, Komitet Inżynierii Lądowej i Wodnej, 92, Warszawa.

10. Łagan, S and Liber-Kneć, A 2017. The application of hyperelastic models for the description of silicone material used for orthopedic liners under load at different speed. (Zastosowanie modeli hipersprężystych w opisie materiału silikonowego wykorzystywanego na linery ortopedyczne poddanego obciążeniu z różną prędkością). Modelowanie Inżynierskie, 31, 62-68.

11. Martins, P, Jorge, RN and Ferreira, A 2006. A comparative study of several material models for prediction of hyperelastic properties: application to silicone silicone-rubber and soft tissues. Strain, 42, 13-147.

12. Nowak, Z 2008. Constitutive modeling and parameter identification for rubber-like materials, Engineering Transactions, 56, 2, 117-157.

13. Ogden, RW 1972. Large deformation isotropic elasticity - on the correlation of theory and experiment for incompressible rubberlike solids, Proceedings of the Royal Society of London. A. Mathematical and Physical Sciences, 326, 1567, 565584.

14. PN-EN ISO 527-1:2012. Plastics - Determination of tensile properties - Part 1: General principles. (Tworzywa sztuczne - Oznaczanie właściwości mechanicznych przy statycznym rozciąganiu - Część 1: Zasady ogólne).

15. PN-EN ISO 527-2:2012. Plastics - Determination of tensile properties - Part 2: Test conditions for various forming techniques. (Tworzywa sztuczne - Oznaczanie właściwości mechanicznych przy statycznym rozciąganiu - Część 2: Warunki badań tworzyw sztucznych przeznaczonych do różnych technik formowania).

16. Rodacki, K 2017. Nośność belek zespolonych drewniano-szklanych poddanych obciążeniom wielokrotnie zmiennym. Praca doktorska, Kraków: Politechnika Krakowska.

17. Stabik, J 2004. Wybrane problemy reologii uplastycznionych polimerów napełnionych. Zeszyty Naukowe. Mechanika/Politechnika Śląska, 143, 1-225.

18. Szeptyński, P 2017, Theory of elasticity (Teoria sprężystości).

19. Śliwa-Wieczorek, K, Zając, B and Kozik, T 2019, Tests of polymeric adhesive joints in the aspect of their application in prefabricated timber structures, in print.

20. Zając, B 2018. Rigid and flexible shear adhesive connections working at elevated temperature. (Ścinane połączenia klejone sztywne i podatne pracujące w podwyższonej temperaturze), Kraków: Wydawnictwo Politechniki Krakowskiej.

Editor received the manuscript: 23.11.2019 